\title{
THE
}

\section{CLASSICAL REVIEW}

\author{
EDITED BY \\ L. D. REYNOLDS \\ AND \\ N. G. WILSON
}

BOARD OF MANAGEMENT

PROF. E. J. KENNEY, M.A., F.B.A. (Chairman)

Prof, W. G. ARNOTT, M.A., Ph.D.; Prof, R. BROWNING, M.A., F.B.A.

Prof. C. COllard, M.A., M.Litt.; Prof. G. R. WATSON, M.A., M.Litt.

(Representing the Council of the Classical Association)

D. A. F. M. RUSSELL, M.A., F.B.A. (Representing the Oxford Philological Society) (Hon. Secretary)

J. DIGGLE, M.A., Ph.D. (Representing the Cambridge Philological Society)

\author{
NEW SERIES \\ VOLUME XXXI \\ (VOL. XCV OF THE CONTINUOUS SERIES)
}

Published for the Classical Association by

OXFORD UNIVERSITY PRESS

1981 
Oxford University Press, Walton Street, Oxford ox2 6DP OXFORD LONDON GLASGOW

NEW YORK TORONTO MELBOURNE WELLINGTON KUALA LUMPUR SINGAPORE HONG KONG TOKYO

DELHI BOMBay CALCUTTA MADRAS KaRACHI

NAIROBI DAR ES SALAAM CAPE TOWN

(C) Oxford University Press, 1981

The British Academy

made a generous contribution towards

the cost of this volume

Printed in Great Britain at the

University Press, Cambridge

JOHN RYLANDS

UNIVERSITY

LIBRARY 


\title{
TABLE OF CONTENTS
}

\author{
Nimber 1
}

\section{REVIEWS}

Ackermann, E. Lukrez und der Mythos (E. J. KENNEY)

Bain, D. Actors and Audience: A Study of Asides and Related Conventions in Greek Drama (J. C. B. LOWE)

Billerbeck, M. Der Kyniker Demetrius (M. T. GRIFFIN)

Boyle, A. J. (ed.) Virgits Ascraean Song. Ramus Essays on the Georgics (J. GRIFFIN)

Brendel, O. J. Prolegomena to the Study of Roman Art (M. A. R. COLLEDGE)

Briggs, W. W., Jr Narrative and Simile from the Georgics in the Aeneid (J. G R IF FIN)

Burkert, W. Structure and History in Greek Mythology and Ritual

(N. J. RICHARDSON)

Cairns, F. Tibullus: A Hellenistic Poet at Rome (R. MAL TBY)

Cantarella, E. Norma e sanzione in Omero: contributo alla protostoria del diritto greco (D. M. MACDOWELL)

Cartledge, P. Sparta and Lakonia. A Regional History 1300-362 B.C.

(F. KIECHLE)

Chilver, G. E. F. A Historical Commentary on Tacitus' Histories I and II (R. J. A. TALBERT)

den Boer, W. Private Morality in Greece and Rome (N. R. E. FISHER)

Di Benedetto, V. L'ideologia del potere e la tragedia greca: Ricerche su Eschilo (C. W. MACLEOD)

Doumas, C. (ed.) Thera and the Aegean World I (E. SCHOFIELD)

Fernández-Galiano, E. Léxico de los himnos de Calímaco (A. Griffiths)

Finley, M. I. Ancient Slavery and Modern Jdeology (P. A. B R U NT)

Garzya, A. (ed.) Euripides, Andromacha (J. DigGLE)

Gentili, B., Prato, C. (edd.) Poetae Elegiaci. Testimonia et Fragmenta. Pars prior (M. L. WEST)

Gigante, M. Civiltà delle forme letterarie nell antico Pompei (M. S. S Mıt H)

Glucker, J. Antiochus and the Late Academy (J. DILLON)

Güngerich, R. Kommentar zum Dialogus des Tacitus (M. WINTER BOTTOM)

Holland, L. A. Lucretius and the Transpadanes (R. MALTBY)

Holwerda, D. (ed.) Scholia Vetera in Nubes (K. J. DOVER)

Irwin, T. Plato, Gorgias (D. S. HUTCHINSON)

JACT Greek Course. The Intellectual Revolution: Selections from Euripides, Thucydides and Plato (H. J. K. USHER)

Johnson, S. Later Roman Britain (P. BAR THOLOMEW)

Johnston, P. A. Vergits Agricultural Golden Age. A Study of the Georgics (J. GRIFFIN)

Jones, B. W. Domitian and the Senatorial Order (B. M. LEviCK)

Jordan, B. The Athenian Navy in the Classical Period (F. D. HAR VEY)

Kahn, C. H. The art and thought of Heraclitus (M. R. WRIGHT)

Koster, W. J. W. (ed.) Scholia Vetera et Recentiora in Aristophanis Vespas (K. J. DOVER)

Lévy, E. Athènes devant la défaite de 404. Histoire d'une crise idéologique (N. R. E. FISHER)

Miles, G. B. Virgits Georgics: A new' Interpretation (J. GR IF FIN)

Mosshammer, A. A. The Chronicle of Eusebius and Greek Chronographic Tradition (W. G. FORREST)

Nichols, F. J. (ed.) An Anthology of Neo-Latin Poetry (M. W. POPE) 
Putnam, M. C.J. Virgils Poem of the Earth: Studies in the Georgics (J. GRIFfIN) 23

Reggiani, R. I proemi degli Annales di Ennio (H. D. JOCELY N) 16

Rickman, G. The Corn Supply of Ancient Rome (D. L. STOCKTON)

Robinson, C. Lucian and his influence in Europe (M. D. MACLEOD) 14

Schaps, D. M. Economic Rights of Women in Ancient Greece (N. R. E. FISHER)

Schofield, M. An essay on Anaxagoras (M. R. WRIGHT) 55

Shackleton Bailey, D. R. Towards a Text of the Anthologia Latina

(E. COURTNEY)

Sourvinou-Inwood, C. Theseus as Son and Stepson. A tentative illustration of the Greek mythological mentality (E. SIMON)

Stadter, P. A. Arrian of Nicomedia (s. HOR NBLOWER)

Stanford, W. B. Enemies of Poetry (K. W. GR ANSDEN)

Tatum, J. Apuleius and The Golden Ass (S. WEST) 46

Urban, R. Wachstum und Krise des Achäischen Bundes (J. BRISCOE) ‘ 89

Walbank, M. B. Athenian Proxenies of the Fifth Century B.C. (D. WhITEHEAD) 87

Wiseman, T.P. Clio's Cosmetics. Three Studies in Greco-Roman Literature (J. BRISCOE)

\section{NOTICES}

Alfieri, V. E. Atomos idea, Torigine del concetto dellatomo nel pensiero greco (G. B. KERFERD)

Aujac, G. Denys d Halicarnasse, Opuscules rhétoriques. Tome $i$ (D. C. INNEs)

Austin, N. J. E. Ammianus on warfare (J. M. ALONSO-NÚÑ̃z)

Balsdon, J. P. V. D. Romans and aliens (J. BR ISCOE)

Baltes, M. Die Weltentstehung des Platonischen Timaios nach den antiken Interpreten, II (G. B. KERFERD)

Barck, C. Wort und Tat bei Homer (O. TA PLIN)

Barratt, P. M. Annaei Lucani Belli Civilis Liber V: a commentary (R. MA YER)

Bartelink, G. J. M. Hieronymus: Liber de optimo genere interpretandi (Epistula 57) (J. H. D. SCOURFIELD)

Berti, E. Profilo di Aristotele (J. BAR Nes)

Blessington, F. C. Paradise Lost and the classical epic (R. JENK YNS)

Bonacasa, N. Arte romana: scultura (M. A. R. COLLEDGE)

Borgeaud, P. Recherches sur le dieu Pan (R. C. T. PAR Ker)

Boswinkel, E., Pestman, P. W., Rupprecht, H.-A. Berichtigungsliste der griechischen Papyrusurkunden aus Ägypten VI (P. J. PA RSONS)

Carson, R. A. G. Principal coins of the Romans II (D. NASH)

Cavajoni, G. A. Supplementum adnotationis super Lucanum: I, libri I-V (R. MAYER)

Cerri, G. Legislazione orale e tragedia greca (J. DIGGLE)

Citti, V. Tragedia e lotta di classe in Grecia (C. W. MACLEOD)

Clarke, J. R. Roman black-and-white figural mosaics (E. W A Y WELL)

Colli, G. La sapienza greca III: Eraclito (J. BA R NES)

Detienne, M. \& Vernant, J.-P. La cuisine du sacrifice en pays grec

(R. G. A. BUXTON)

$\begin{array}{ll}\text { Dörrie, H. Platonica minora (R. T. WA LliS) } & 129 \\ \text { Dover, Sir Kenneth Plato, Symposium (F. H. SA NDBACH) } & 126\end{array}$

Eck, W. Die staatliche Organisation Italiens in der hohen Kaiserzeit (N. PURCELL) 137

Firmani, A. Il lessico degli Annali di Quinto Ennio (vv. 1-226) attra verso le edizioni dal 1564 (H. D. JOCELYN)

Gallo, I. Un papiro della Vita del filosofo Secondo e la tradizione medioevale del bio. (S. R. WEST)

Graves, R. P. A. E. Housman: the scholar-poet (J. DIGGLE)

Hawkes, C. Britain and Julius Caesar (R. GOODBUR N) 
Kanta, A. The Late Minoan III period in Crete (M. РО Рн Ам)

Kennedy, G. A. Classical Rhetoric and its Christian and secular tradition from ancien to modern times (M. WINTERBOT TOM)

Kindermann, U. Satyra: die Theorie der Satire im Mittellateinischen

(A. B. E. HOOD)

Kohlwes, K. Christliche Dichtung und stilistische Form bei Paulinus von Nola (P. G. WALSH)

Liénard, E. Répertoires prosodiques et métriques. Lucrèce, Valerius Flaccus, Germ anicus (E. J. KENNEY)

Loeb, E. H. Die Geburt der Götter in der griechischen Kunst der klassischen Ze (J. BOARDMAN)

McLeish, K. The theatre of Aristophanes (N. G. WILSON)

Magno, P. Quinto Ennio (H. D. JOCELYN)

Mastandrea, P. Cornelio Labeone: un neoplatonico latino (R. M. OGILVIE)

Mastromarco, G. Il pubblico di Eronda (P. J. PA RSONS)

Meillier, C. Callimaque et son temps (F. CAIRNS)

Montanari, F. Studi di flologia omerica antica, I (S. R. WEST)

Murrin, M. The allegorical epic: essays in its rise and decline (K. W. GR ANSDEN)

Narducci, E. La provvidenza crudele: Lucano e la distruzione dei miti augustei (R. MAYER)

Omar, S. Das Archiv des Soterichos (P. Soterichos) (J. D. THOMAS)

Paduano, G. Sui Persiani di Eschilo (J. DIGgLE)

Pleket, H.W. \& Stroud, R.S. Supplementum epigraphicum graecum XXVI (P. FRASER)

Radici Colace, P. Choerili Samii reliquiae (M. L. WEST)

Rambaux, C. Tertullien face aux morales des trois premiers siècles (R. M. OGIL VIE)

Rizzo S. La tradizione manoscritta della Pro Cluentio di Cicerone (M. WINTERBOTтом)

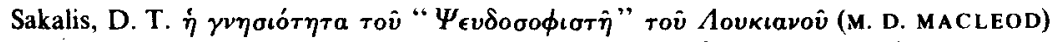

Schein, S. L. The iambic trimeter in Aeschylus and Sophocles (R. SEAFORD)

Schwartz, J. et al. Papyrus grecs de la Bibliothèque nationale et universitaire de Strasbourg nos. $681-700$ (R. COLES)

Scodel, R. The Trojan trilogy of Euripides (J. DIGGLE)

Seibert, J. Die politischen Flüchtlinge und Verbannten in der griechischen Geschichte (D. M. LEWIS)

Shackleton Bailey, D. R. Cicero: Select Letters (E. RAwSON)

Stockton, D. The Gracchi (A. LINTOTT)

Stroh, W. Taxis und Taktik: die advokatorische Dispositionskunst in Ciceros Gerichtsreden (D. C. INNES)

Syme, Sir Ronald Roman papers (J. CROOK)

Tsagarakis, $\mathrm{O}$. Nature and background of major concepts of divine power in Homer (o. TAPLIN) 


\section{Number 2}

\section{REVIEWS}

Bosworth, A. B. A historical commentary on Arrian's History of Alexander. Vol. I, Commentary on Books 1-3 (S. HOR NBLOWER)

Braun, L. Scenae suppositiciae, oder Der falsche Plautus (H. D. JOCELYN)

Brize, P. Die Geryoneis des Stesichoros und die frühe griechische Kunst (D. C. KUR TZ)

Brown, P. The making of late antiquity (E. D. HUNT)

Capecci, A. Struttura e fine: la logica della teleologia aristotelica (R. W. SHAR PLES) 223

Capponi, F. Ornithologia latina (W. G. A R NOT T) 269

Chiarini, G. La recita: Plauto, la farsa, la festa (H. D. JOCELYN) 194

Cohen, S. J. D. Josephus in Galilee: his Vita and development as a historian (T. RAJA K) 250

Coles, R. A. \& Haslam, M. W. The Oxyrhynchus Papyri XLVII (W. LUPPE) 267

Colonna, A. Sophocles, Fabulae II (H. LLOYD-JONES) 167

Dalfen, J. (ed.) Marcus Aurelius, ad se ipsum libri xii (F. H. SA NDBACH) 188

Dawe, R. D. Studies on the text of Sophocles III and Sophocles, Tragoediae II (H. LLOYD-JONES)

Degl'Innocenti Pierini, R. Studi su Accio (H. D. JOCEL YN)

De Martino, F. Storia economica di Roma antica (J. BRISCOE) 253

Dover, K. J. et al. Ancient Greek literature (L. M. STYLER) 214

Dupont-Roc, R. \& Lallot, J. Aristote: La Poétique (B. R. REES) 178

Edwards, R. B. Kadmos the Phoenician: a study in Greek legends of the Mycenaean Age (R. F. WILLETTS)

Fedeli, P. Sesto Properzio: Il primo libro delle Elegie. Introduzione, testo critico e commento (J. A. RICHMOND)

Flashar, H. (ed.) Le classicisme à Rome aux lers siècles avant et après J.-C. (R. MA YER)

Foster, K. P. Aegean Faience of the Bronze Age (s. HOOD)

Gaide, F. (ed.) Avianus: Fables (M. D. REEvE)

Gomme, A. W., Andrewes, A., Dover, K. J. A historical commentary on Thucydides, Vol. 5, Book 8 (D. L. STOCK TON)

Goulet, R. Cléomède: Théorie élémentaire (1. BULMER-THOMAS)

Grant, M. The Etruscans (R. M. OGILVIE)

Greenhalgh, P. Pompey (D. L. STOCK TON)

Griffin, J. Homer on life and death and Homer (A. M. BOWIE)

Habicht, C. Untersuchungen zur politischen Geschichte Athens im 3. Jahrhundert v. Chr. (P. M. FR A SER)

Hanslik, R. (ed.) Sex. Propertii Elegiarum Libri IV (E. J. KENNEY)

Huntingford, G. W. B. The Periplus of the Erythraean Sea (E. W. GR AY)

Jenkyns, R. The Victorians and Ancient Greece (E. J. KENNEY)

Kamerbeek, J. C. The plays of Sophocles III \& VI (H. LLOYD-JONES) 173

Loi, V. Origini e caratteristiche della latinità cristiana (L. A. HOLFORD-STREVENS) 230

Lyne, R. O. A. M. The Latin love poets: from Catullus to Horace (N. RUDD) 216

Mango, C. Byzantium: the empire of New Rome (M. ANGOLD) 278

Martindale, J. R. The prosopography of the Later Roman Empire, II: A.D. 395-527 (J. H. W. G. LIEBESCHUETZ)

Moon, W. \& Berge, L. Greek vase-painting in Midwestern collections (D. C. KURTZ) 264

Nisetich, F. J. (tr.) Pindar's Victory Songs (M. C. HOW A TSON) 162

Palagia, O. Euphranor (G. B. WAYWELL) 261

Palmer, L. R. The Greek language (J. H. W. PENNEY) 227

Peretti, A. Il Periplo di Scilace (E. W. GRAY) 273 
Potter, T. W. The changing landscape of South Etruria (P. GA RNSEY) 244

Prato, C. \& Micalella, D. (edd.) Giuliano Imperatore, Misopogon (A. F. NOR MAN) 190

Prinz, F. Gründungsmythen und Sagenchronologie (G. HUX LEY) 225

Pritchett, W. K. The Greek state at war. Part III: Religion (N. G. L. HAMmOND) 238

Radt, S. L. Tragicorum graecorum fragmenta IV: Sophocles (H. LLOYD-JONES) 175

Riikonen, H. Die Antike im historischen Roman des 19. Jahrhunderts (E. J. KEN NEY) 280

Rösler, W. Dichter und Gruppe (R. C. T. PARKER) 159

Schoonhoven, H. Elegiae in Maecenatem: prolegomena, text, commentary (M. D. REEVE) 204

Sedlar, J. W. India and the Greek world (E. W. GR A Y) 233

Shackleton Bailey, D. R. (ed.) Cicero: Epistulae ad Quintum fratrem et $M$. Brutum (E. RAWSON)

Thomsen, R. King Servius Tullius (R. M. OGILVIE) 245

Traglia, A. \& Aricò, G. (edd.) Opere di Publio Papinio Stazio (D. E. HILL) 207

Williams, G. Figures of Thought in Roman poetry (R. O. A. M. LYNE) 218

Zagagi, N. Tradition and originality in Plautus (H. D. JOCELYN) 192

Zilliacus, H. et al. Corpus Papyrorum Raineri VII: Griechische Texte IV (J. D. Thомas) 265

\section{NOTICES}

Aalto, P. Classical Studies in Finland 1828-1918 (E. J. KEN NEY) 330

Bagnall, R. S., Sijpesteijn, P. J., Worp, K. A. Greek Ostraka at Leiden (R. CoLEs) 325

Beierwaltes, W. Identität und Differenz (G. J. P. O'D A LY)

Bertini, F. and others Commedie Latine del XII e XIII Secolo, Vol. II (J. C. McKEOWN) 328

Beyer, I. Die Tempel von Dreros und Prinias (A. M. SNODG R ASS) 316

Bickerman, E. J. Chronology of the Ancient World. Revised Edition (D. M. LEWIS) 309

Böhm, R. G. Vigiliae Tullianae (F. R. D. GOODYEAR) 294

Bordenache Battaglia, G. Le ciste prenestine I. Corpus I (F. R. SER RA RIDGWAY) 323

Burger, R. Plato's Phaedrus: A Defense of a Philosophic Art of Writing (M. BURNYEAT) 299

Buschor, E. On the Meaning of Greek Statues (G. B. WAYWELL) 318

Camps, W. A. An Introduction to Homer (J. B. H A INSWORTH) 284

Cèbe, J.-P. Varron, Satires Ménippées, tome 5 (R. AST BUR Y) 294

Chantraine, P. Dictionnaire étymologique de la langue grecque. Tome IV-2 (D. M. JONES) 306

Clairmont, R. E. A Commentary on Seneca's Apocolocyntosis Divi Claudii (P. T. EDEN) 328

Clarke, M. L. The Noblest Roman. Marcus Brutus and his Reputation (E. RAWSON) 327

Clayman, D. L. Callimachus' Iambi (F. CAIR Ns) 287

Craik, E. M. The Dorian Aegean (s. Hood) 315

Daiber, H. Aetius Arabus: die Vorsokratiker in arabischer Überlieferung (C. S. F. BURNETT) 304

de Jonge, P. Philological and Historical Commentary on Ammianus Marcellinus XVIII (R. BROWNING)

Dinsmoor, W. B., Jr. The Propylaia to the Athenian Acropolis, Vol. I (J. J. Coulton)

Döring, K. Exemplum Socratis (A. A. LONG)

Emlyn-Jones, C. J. The Ionians and Hellenism (P. W A L COT)

Fitzhardinge, L. F. The Spartans (D. J. R. WILlıams)

Fone, B. R. S. (ed.) Hidden Heritage. History and the Gay Imagination (K. J. DovE R) 326

Frier, B. W. Libri annales pontificum maximorum (J. BRISCOE) 311

Gaiser, K. Das Philosophenmosaik in Neapel (R. J. LING) 322

Gottlieb, G. Ost und West in der christlichen Kirche des 4. und 5. Jahrhunderts (E. D. HUNT)

Green, J. R. Corpus Vasorum Antiquorum, New Zealand, Fasc. l (D. J. R. WIL LIA MS) 320

Haynes, D. Greek Art and the Idea of Freedom (R. R. R. SMITH) 317

Herrera Zapién, T. Publio Ovidio Nasón, Heróidas (E. J. K ENNEY) 293 
Jensen, M. S. The Homeric question and the oral-formulaic theory (P. V. JONES)

Jones, T. B. In the Twilight of Antiquity (E. D. HUNT)

Kádár, Z. Survivals of Greek Zoological Illuminations in Byzantine Manuscripts (K. SNIPES)

Klein-Franke, F. Die klassische Antike in der Tradition des Islam (F. W. ZI M MER MANN)

Knell, H. Grundzüge der griechischen Architektur (R. A. TOMLINSON)

Lear, J. Aristotle and Logical Theory (D. CHARLES)

Lee, G. Virgil's Eclogues (R. G. M. NISBET)

Lo Cascio, F. Sulla autenticità delle epistole di Apollonio Tianeo (G. W. BOWERSOCK)

Lowry, J. M. P. The Logical Principles of Proclus' $\Sigma T O I X E I \Omega \Sigma I \Sigma$ QEOAOIIKH (A. SHEP PAR D)

Lundström, S. Ovids Metamorphosen und die Politik des Kaisers (J. C. McK EOWN)

Macfarlane, K. N. Isidore of Seville on the Pagan Gods (Origines VIII, II) (P. Godm A N)

Mack, S. Patterns of Time in Vergil (A. CR A B BE)

Massa-Pairault, F.-H. and Pailler, J. M. La Maison aux Salles Souterraines (Bolsena V) (R. M. OGILVIE)

Montanari Caldini, R. Horos e Properzio (J. A. RiCHMOND)

Nippel, W. Mischverfassungstheorie und Verfassungsrealität in Antike und früher Neuzeit (J. M. ALONSO-NÚÑ̃Z)

Pelletier, A. Le Sanctuaire Métroaque de Vienne (R. M. OgilviE)

Petersmann, G. Themenführung und Motiventfaltung in der Monobiblos des Properz (J. C. MCKEOWN)

Philipp, K. Zeugung als Denkform in Platons geschriebener Lehre (A. SHE P PA RD)

Philippides, M. The Fall of the Byzantine Empire: A Chronicle by George Sphrantzes (R. BROWNING)

Rocca-Serra, G. Censorinus, Le jour natal (M. WINTER BOT TOM)

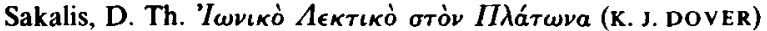

Sallis, J. and Maly, K. Heraclitean Fragments (M. R. WR IGHT)

Scullard, H. H. A History of the Roman World 753 to 146 B.C. Fourth Edition (D. L. STOCKTON)

Shipp, G.P. Modern Greek Evidence for the Ancient Greek Vocabulary (A. C. MOORHOUSE)

Smith, P. Nursling of Mortality. A Study of the Homeric Hymn to Aphrodite (R. JA NKO)

Sordi, M. (ed.) Conoscenze etniche e rapporti di convivenza nell antichità (J. B RISCOE)

Speidel, M. P. Mithras-Orion. Greek Hero and Roman Army God (R. M. OGILVIE)

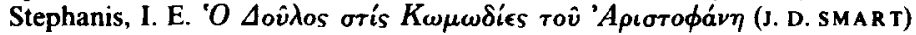

Stewart, A. ATTIKA. Studies in Athenian Sculpture of the Hellenistic Age (C. E. VAFOPOULOU-RICHARDSON)

Szlezák, T. A. Platon und Aristoteles in der Nuslehre Plotins (M. J. A TKINSON)

Turner, E. G. Greek Papyri. Second Edition (A. K. Bow ma N)

Whitting, P. Byzantium: An Introduction (R. BRow NING) 


\title{
TABLE OF CONTENTS
}

\author{
Number 2
}

\section{REVIEWS}

Bosworth, A. B. A historical commentary on Arrian's History of Alexander. Vol. I, Commentary on Books 1-3 (S. HOR N BLOWER)

Braun, L. Scenae suppositiciae, oder Der falsche Plautus (H. D. JOCELYN)

Brize, P. Die Geryoneis des Stesichoros und die frühe griechische Kunst (D. C. KUR T Z)

Brown, P. The making of late antiquity (E. D. HUNT)

Capecci, A. Struttura e fine: la logica della teleologia aristotelica (R. W. SHARPLES)

Capponi, F. Ornithologia latina (w. G. A R NOT T)

Chiarini, G. La recita: Plauto, la farsa, la festa (H. D. JOCELYN)

Cohen, S. J. D. Josephus in Galilee: his Vita and development as a historian (T. RA JAK)

Coles, R. A. \& Haslam, M. W. The Oxyrhynchus Papyri XLVII (w. LU P PE)

Colonna, A. Sophocles, Fabulae II (H. LLOYD-JONES)

Dalfen, J. (ed.) Marcus Aurelius, ad se ipsum libri xii (F. H. SANDBACH)

Dawe, R. D. Studies on the text of Sophocles III and Sophocles, Tragoediae II (H. LLOYD-JONES)

Degl'Innocenti Pierini, R. Studi su Accio (H. D. JoCely N)

De Martino, F. Storia economica di Roma antica (J. BRISCOE)

Dover, K. J. et al. Ancient Greek literature (L. M. STY LER)

Dupont-Roc, R. \& Lallot, J. Aristote: La Poétique (B. R. REES)

Edwards, R. B. Kadmos the Phoenician: a study in Greek legends of the Mycenaean Age (R. F. WILLETTS)

Fedeli, P. Sesto Properzio: Il primo libro delle Elegie. Introduzione, testo critico e commento (J. A. RICHMOND)

Flashar, H. (ed.) Le classicisme à Rome aux lers siècles avant et après J.-C. (R. MA YER)

Foster, K. P. Aegean Faience of the Bronze Age (s. HOOD)

Gaide, F. (ed.) Avianus: Fables (M. D. REEvE)

Gomme, A. W., Andrewes, A., Dover, K. J. A historical commentary on Thucydides, Vol. 5 , Book 8 (D. L. STOCK TON)

Goulet, R. Cléomède: Théorie élémentaire (1. BUL MER-THOMAS)

Grant, M. The Etruscans (R. M. OGILVIE)

Greenhalgh, P. Pompey (D. L. STock TON)

Griffin, J. Homer on life and death and Homer (A. M. BOWIE)

Habicht, C. Untersuchungen zur politischen Geschichte Athens im 3. Jahrhundert v. Chr. (P. M. FRASER)

Hanslik, R. (ed.) Sex. Propertii Elegiarum Libri IV (E. J. KENNEY)

Huntingford, G. W. B. The Periplus of the Erythraean Sea (E. W. GRAY)

Jenkyns, R. The Victorians and Ancient Greece (E. J. KENNEY) 280

Kamerbeek, J. C. The plays of Sophocles III \& VI (H. LLOYD-JONES) 173

Loi, V. Origini e caratteristiche della latinità cristiana (L. A. HOLFORD-STREVENS) 230

Lyne, R. O. A. M. The Latin love poets: from Catullus to Horace (N. RUDD) 216

Mango, C. Byzantium: the empire of New Rome (M. ANGOLD) 278

Martindale, J. R. The prosopography of the Later Roman Empire, II: A.D. 395-527 (J. H. W. G. LIEBESCHUETZ) 
Palmer, L. R. The Greek language (J. H. W. PENNEY) 227

Peretti, A. Il Periplo di Scilace (E. W. GRA Y) 273

Potter, T. W. The changing landscape of South Etruria (P. GAR NSEY)

Prato, C. \& Micalella, D. (edd.) Giuliano Imperatore, Misopogon (A. F. NOR MAN) 190

Prinz, F. Gründungsmythen und Sagenchronologie (G. HUXLEY) 225

Pritchett, W. K. The Greek state at war. Part III: Religion (N. G. L. HAMmond) 238

Radt, S. L. Tragicorum graecorum fragmenta IV: Sophocles (H. LLOYD-JONES) 175

Riikonen, H. Die Antike im historischen Roman des 19. Jahrhunderts (E. J. K E N NEY) 280

Rösler, W. Dichter und Gruppe (R. C. T. PAR KER) 159

Schoonhoven, H. Elegiae in Maecenatem: prolegomena, text, commentary (M. D. REEVE) 204

Sedlar, J. W. India and the Greek world (E. W. GRAY) 233

Shackleton Bailey, D. R. (ed.) Cicero: Epistulae ad Quintum fratrem et $M$. Brutum (E. RAWSON)

Thomsen, R. King Servius Tullius (R. M. OGIL viE)

Traglia, A \& Aricò, G. (edd) Opere di Publio Papinio Stazio (D E HILL)

Williams, G. Figures of Thought in Roman poetry (R. O. A. M. LYNE) 218

Zagagi, N. Tradition and originality in Plautus (H. D. JOCELYN) 192

Zilliacus, H. et al. Corpus Papyrorum Raineri VII: Griechische Texte IV (J. D. THOMAs) 265

\section{NOTICES}

Aalto, P. Classical Studies in Finland 1828-1918 (E. J. KENNEY) 330

Bagnall, R. S., Sijpesteijn, P. J., Worp, K. A. Greek Ostraka at Leiden (R. COLEs) 325

Beierwaltes, W. Identität und Differenz (G. J. P. O'D A L Y) 304

Bertini, F. and others Commedie Latine del XII e XIII Secolo, Vol. II (J. C. MckEOWN) 328

Beyer, I. Die Tempel von Dreros und Prinias (A. M. SNODGR ASs) 316

Bickerman, E. J. Chronology of the Ancient World. Revised Edition (D. M. LEWIS) 309

Böhm, R. G. Vigiliae Tullianae (F. R. D. GOODYEAR) 294

Bordenache Battaglia, G. Le ciste prenestine I. Corpus 1 (F. R. SER RA RIDGWAY) 323

Burger, R. Plato's Phaedrus: A Defense of a Philosophic Art of Writing (M. BURNYEAT) 299

Buschor, E. On the Meaning of Greek Statues (G. B. WAYWELL) 318

Camps, W. A. An Introduction to Homer (J. B. HAINSWORTH) 284

Cèbe, J.-P. Varron, Satires Ménippées, tome 5 (R. AST B U R Y) 294

Chantraine, P. Dictionnaire étymologique de la langue grecque. Tome IV-2 (D. M. JONES) 306

Clairmont, R. E. A Commentary on Seneca's Apocolocyntosis Divi Claudii (P. T. EDEN) 328

Clarke, M. L. The Noblest Roman. Marcus Brutus and his Reputation (E. RAwSON) 327

Clayman, D. L. Callimachus' Iambi (F. CAIR NS) 287

Craik, E. M. The Dorian Aegean (s. HOOD) 315

Daiber, H. Aetius Arabus: die Vorsokratiker in arabischer Überlieferung (C. S. F. BURNETT) 304

de Jonge, P. Philological and Historical Commentary on Ammianus Marcellinus XVIII (R. BROWNING)

Dinsmoor, W. B., Jr. The Propylaia to the Athenian Acropolis, Vol. I (J. J. Coulton)

Döring, K. Exemplum Socratis (A. A. LONG)

Emlyn-Jones, C. J. The Ionians and Hellenism (P. W A LCOT) 310

Fitzhardinge, L. F. The Spartans (D. J. R. WIL LiAms) 309

Fone, B. R. S. (ed.) Hidden Heritage. History and the Gay Imagination (K. J. Dover) 326

Frier, B. W. Libri annales pontificum maximorum (J. BRISCOE) 311

Gaiser, K. Das Philosophenmosaik in Neapel (R. J. LING) 322

Gottlieb, G. Ost und West in der christlichen Kirche des 4. und 5. Jahrhunderts (E. D. HUNT)

Green, J. R. Corpus Vasorum Antiquorum, New Zealand, Fasc. I (D. J. R. WILLIAMs) 320 
Haynes, D. Greek Art and the Idea of Freedom (R. R. R. SMITH) 317

Herrera Zapién, T. Publio Ovidio Nasón, Heróidas (E. J. KENNEY) 293

Jensen, M. S. The Homeric question and the oral-formulaic theory (P. V. Jones) 284

Jones, T. B. In the Twilight of Antiquity (E. D. HUNT)

Kádár, Z. Survivals of Greek Zoological Illuminations in Byzantine Manuscripts (K. SNIPES)

Klein-Franke, F. Die klassische Antike in der Tradition des Islam (F. W. ZIMMERMANN)

Knell, H. Grundzüge der griechischen Architektur (R. A. TOMLINSON)

Lear, J. Aristotle and Logical Theory (D. CHARLES)

Lee, G. Virgil's Eclogues (R. G. M. NISBET)

Lo Cascio, F. Sulla autenticità delle epistole di Apollonio Tianeo (G. W. BowERSOCK)

Lowry, J. M. P. The Logical Principles of Proclus' $\Sigma T O I X E I S \Sigma I \Sigma$ QEOAOTIKH (A. SHEP PAR D)

Lundström, S. Ovids Metamorphosen und die Politik des Kaisers (J. C. MckeOWN)

Macfarlane, K. N. Isidore of Seville on the Pagan Gods (Origines VIII, 11) (P. GODMA N)

Mack, S. Patterns of Time in Vergil (A. CRA B BE)

Massa-Pairault, F.-H. and Pailler, J. M. La Maison aux Salles Souterraines (Bolsena V) (R. M. OGILVIE)

Montanari Caldini, R. Horos e Properzio (J. A. RICHMOND)

Nippel, W. Mischverfassungstheorie und Verfassungsrealität in Antike und früher Neuzeit (J. M. A LONSO-NÚÑ̃EZ)

Pelletier, A. Le Sanctuaire Métroaque de Vienne (R. M. OGILVIE)

Petersmann, G. Themenführung und Motiventfaltung in der Monobiblos des Properz (J. C. McKEOWN)

Philipp, K. Zeugung als Denkform in Platons geschriebener Lehre (A. SHEP PARD)

Philippides, M. The Fall of the Byzantine Empire: A Chronicle by George Sphrantzes (R. BROWNING)

Rocca-Serra, G. Censorinus, Le jour natal (M. WINTER BOTTOM)

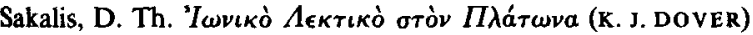

Sallis, J. and Maly, K. Heraclitean Fragments (M. R. WRIGHT)

Scullard, H. H. A History of the Roman World 753 to 146 B.C. Fourth Edition (D. L. STOCKTON)

Shipp, G. P. Modern Greek Evidence for the Ancient Greek Vocabulary (A. C. MOORHOUSE)

Smith, P. Nursling of Mortality. A Study of the Homeric Hymn to Aphrodite (R. JA NKo)

Sordi, M. (ed.) Conoscenze etniche e rapporti di convivenza nell' antichità (J. BR ISCOE)

Speidel, M. P. Mithras-Orion. Greek Hero and Roman Army God (R. M. ogilviE)

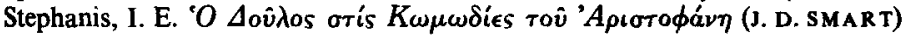

Stewart, A. ATTIKA. Studies in Athenian Sculpture of the Hellenistic Age (C. E. VAFOPOULOU-RICHARDSON)

Szlezák, T. A. Platon und Aristoteles in der Nuslehre Plotins (M. J. A TKINSON)

Turner, E. G. Greek Papyri. Second Edition (A. K. Bow MaN)

van den Bruwaene, M. Cicéron, De Natura Deorum, livre II (M. WINTER Bot ToM) 295

van Royen, R. A. and Isaac, B. H. The Arrival of the Greeks (S. HOOD) 314

Whitting, P. Byzantium: An Introduction (R. B ROW NING) 332

Wiseman, A. and P. Julius Caesar: The Battle for Gaul (J. D. LEACH) 312 